"Role of travel and tourism sector in the attainment of Vision 2030 in Saudi Arabia: An analytical study"

\begin{tabular}{|c|c|c|}
\hline AUTHORS & Anas A. Salameh (iD) & Anis Ali (i) \\
\hline ARTICLE INFO & \multicolumn{2}{|c|}{$\begin{array}{l}\text { Anis Ali and Anas A. Salameh (2021). Role of travel and tourism sector in the } \\
\text { attainment of Vision } 2030 \text { in Saudi Arabia: An analytical study. Problems and } \\
\text { Perspectives in Management, 19(2), 276-290. doi:10.21511/ppm.19(2).2021.23 }\end{array}$} \\
\hline DOI & \multicolumn{2}{|c|}{ http://dx.doi.org/10.21511/ppm.19(2).2021.23 } \\
\hline RELEASED ON & \multicolumn{2}{|l|}{ Thursday, 17 June 2021} \\
\hline RECEIVED ON & \multicolumn{2}{|l|}{ Thursday, 11 February 2021} \\
\hline ACCEPTED ON & \multicolumn{2}{|l|}{ Tuesday, 08 June 2021} \\
\hline & \multicolumn{2}{|l|}{$((c)$ EY } \\
\hline LICENSE & \multicolumn{2}{|c|}{$\begin{array}{l}\text { This work is licensed under a Creative Commons Attribution } 4.0 \text { International } \\
\text { License }\end{array}$} \\
\hline JOURNAL & \multicolumn{2}{|c|}{ "Problems and Perspectives in Management" } \\
\hline ISSN PRINT & \multicolumn{2}{|l|}{$1727-7051$} \\
\hline ISSN ONLINE & \multicolumn{2}{|l|}{$1810-5467$} \\
\hline PUBLISHER & \multicolumn{2}{|c|}{ LLC "Consulting Publishing Company "Business Perspectives" } \\
\hline FOUNDER & \multicolumn{2}{|c|}{ LLC "Consulting Publishing Company "Business Perspectives" } \\
\hline$\delta^{0}$ & $G$ & 三:こ \\
\hline NUMBER OF REFERENCES & NUMBER OF FIGURES & NUMBER OF TABLES \\
\hline 35 & 0 & 7 \\
\hline
\end{tabular}

(c) The author(s) 2021. This publication is an open access article. 




\section{BUSINESS PERSPECTIVES}

LLC "CPC "Business Perspectives" Hryhorii Skovoroda lane, 10, Sumy, 40022, Ukraine www.businessperspectives.org
Received on: $11^{\text {th }}$ of February, 2021 Accepted on: $8^{\text {th }}$ of June, 2021 Published on: $17^{\text {th }}$ of June, 2021

() Anis Ali, Anas A. Salameh, 2021

Anis Ali, Ph.D., Assistant Professor, Department of Management, Prince Sattam Bin Abdulaziz University, Saudi Arabia. (Corresponding author)

Anas A. Salameh, Ph.D., Assistant Professor, Department of Management Information Systems, Prince Sattam Bin Abdulaziz University, Saudi Arabia.
This is an Open Access article, distributed under the terms of the Creative Commons Attribution 4.0 International license, which permits unrestricted re-use, distribution, and reproduction in any medium, provided the original work is properly cited.

Conflict of interest statement: Author(s) reported no conflict of interest

Anis Ali (Saudi Arabia), Anas A. Salameh (Saudi Arabia)

\title{
ROLE OF TRAVEL AND TOURISM SECTOR IN THE ATTAINMENT OF VISION 2030 IN SAUDI ARABIA: AN ANALYTICAL STUDY
}

\begin{abstract}
Tourism is the main service industry significantly developing in the world. It is recognized as the critical factor in economic improvement in various countries. Saudi Arabia is one of the oldest and most famous spots for pilgrimage tourism due to its Islamic heritage. The study analyzes data available on the websites of the Saudi government to specify the contribution of travel and tourism revenue to the economy and its trend, occupancy of residential, and transportation capacity. A tourism satisfaction questionnaire was administered online to get the responses of Saudi nationals and residents related to tourism infrastructure, facilities, and other tourism services in Saudi Arabia. Ranks and percentage analysis were applied to get the relational satisfaction of tourists. Index numbers, ratios, percentages, and coefficient of variations were applied to get the trend, yearly fluctuations, variations, weights, and contribution of tourism avenues. There is a positive but low degree correlation between tourism revenue and the GDP of Saudi Arabia for the period from 2010 to 2018. The results indicate either negative or negligibly positive revenue growth of the accommodation/hotel services, food services, and air transportation. Two-thirds of tourists are either strongly satisfied or satisfied with essential and other tourism services and facilities in Saudi Arabia. Apart from tourist satisfaction, the Saudi government may consider a variety of services as per the economic level of the targeted tourists, and softening of visiting visa procedures and fees to enhance tourism revenue of major contributors for the positive and progressive development to the economy.
\end{abstract}

\section{Keywords}

JEL Classification

\section{INTRODUCTION}

In recent years, tourism has been one of the most significant growing industries worldwide and is currently retained to be one of the main service manufacturers in the growing economies. Tourism is a critical factor in the economic improvement strategy for various countries. As tourism can produce income, wealth, and foreign exchange earnings, various countries have joined the competition for attracting domestic and foreign tourists. Tourism has now become one of the principal sources of revenue for the economies. Saudi Arabia is one of the oldest and most famous spots for pilgrimage tourism due to its Islamic heritage. Due to the economic development influenced by the exploration of petroleum and other resources, other sorts of tourism (domestic and outbound) have developed to fill the growing demands of Saudi Arabia's population. Factors like temperature, humidity, climate, and geographical position of the Kingdom are distinguished internationally with deserts, plains, high mountains, hills, which have a great effect in attracting tourists. Saudi Vision 2030 has focused on enhancing travel and tourism, which improves the Saudi economy expectedly. Many people around the world visit Saudi Arabia for different purpos- 
es such as religious, cultural, medical, and sports tourism. Millions of Muslims visit Saudi Arabia every year for Umrah and Hajj pilgrimages. Cultural tourists have been engaged in understanding Islamic values, traditions, and civilizations from ancient times to the present such as visiting ancient and holy sites like Madain Salih. There are also places famous for mineral water recommended for curing diseases. There are great facilities in the Kingdom for attending sports tourism such as water-sports, hunting, horse and camel racing, which are very popular in the Kingdom, as well as watching or participating in a sporting occasion. Saudi Arabia is playing a significant role in promoting and organizing sports events, and also supporting and participating the sports events in GCC countries. Over the prior few decades, tourism has become a global phenomenon. Tourism has been one of the fastest-growing sectors of the world economy and is generally known for its contribution to local and national levels of economic improvement. The tourism sector is one of the most promising parts of the revenue diversification, and Saudi Vision 2030 visualizes the tourism sector as a significant grant or to job creation, given the governmental plan of expanding the number of jobs opportunities in the tourism sector by almost $50 \%$ up to 1.5 million by 2020 .

There are three main objectives of the Saudi Vision 2030 i.e., energetic and enthusiastic society, prosperous economy, and a positively dreaming ambitious nation. The growth and development of the tourism sector of Saudi Arabia will nourish the aims and objectives of Saudi Vision 2030 by diversifying the economy, generating employment, and spreading its culture and heritage in the world. Saudi Arabian government develops its tourism infrastructure in the whole country for national and international tourism. With the private sector cooperation, the Saudi government plans to construct 150,000 rooms in the coming three years and 500,000 rooms by 2030 with the cooperation with local and foreign investors. The COVID-19 pandemic declined the number of passengers by 26 million and affected 200,000 jobs in the tourism sector of Saudi Arabia. To overcome the negativity of the pandemic, the Saudi government initiates to help the private sector, and the tourism sector is targeted in the initiatives. For local tourists, the Saudi government launched the Saudi summer season program that considers the 10 tourism spots in the country (Ministry of Tourism of Saudi Arabia, 2020) to enhance the tourism revenue.

\section{LITERATURE REVIEW}

Damanhouri (2017) conducted a study regarding the social and cultural aspects of Saudi Arabian tourists and found that family and religious visitors are frequent visitors in Saudi Arabia. Further, it was suggested that the government should provide the transport facility within Makkah city and focus on the health, hygiene, and cleanness facilities during Hajj time specifically. There should be special arrangements for the translators for the foreign tourists. Yusuf (2014) stated that the Middle East is the most underdeveloped tourism place in the world. It was indicated that there is an ample number of opportunities available in the tourism sector, while some cultural and infrastructural factors slow the growth and development of tourism in Saudi Arabia. Khan and Alam (2014) stated that medical tourism has become important in the economy. Saudi Arabian medical system can be developed to attract international medical tourists. It was suggested to develop modern and well-equipped hospi- tals, specialists and stable foreign-trained doctors, and a well-established private health care sector in Saudi Arabia. Khan (2016) focused on diversification of the economy and modernization of the tourism sector to enhance the contribution to the economy. Khan and Callanan (2017) advocated the standardization of the Islamic terms in the context of tourism to make religious tourism convenient for Islamic tourists. Esmail (2018) explained that the industrial sector has a vital impact on the growth and development of the developing economy, and the tourism sector is the most potential sector in the Saudi economy. Mansour and Mumuni (2019) explored motivations and attitudes regarding tourism destinations and activities in Saudi Arabia and found that the safety, security, and cooperation of the local government play a vital role in the development of tourism. Lack of entertaining tourism spots, tourism information, weaker tourism organization services, and harsh weather during summer are the obstacles in the development of Saudi tourism. The focus was on Saudi inhabitants' attitude 
towards local tourism and negativity towards local tourism comparatively to foreign tourism was found. Monshi and Scott (2017) suggested developing local festivals, events, and celebrations. In Saudi Arabia, sports events can be promoted to enhance local and international tourism and collaboration can be established with the neighboring countries. Abuhjeeleh (2019) stated that tourism accounts for $5 \%$ of the world's GDP and $8 \%$ of total employment in the world. Saudi Arabia started to diversify the economy. Tourism can be a better option as many places in Saudi Arabia are undiscovered and undisclosed. The government of Saudi Arabia is softening the rules for tourists to enhance the number of tourists,and to reduce the dependency on oil income ultimately. The oil and other petroleum products represent $53 \%$ of the Saudi GDP, which makes the Saudi economy exposed to the negative impact of oil price fluctuations (Mahroum \& Al-Saleh, 2016). Saudi Arabia, thus, can no longer depend solely on oil and public spending for growth. According to Al-Kibsi et al. (2015), although Saudi Arabia witnessed a prosperous period from 2003 to 2013 , it yielded an annual productivity growth among developing countries. The importance of diversifying economic activities is being pivotal for the Saudi government because it reduces the side effects of dependency on oil revenues as the main source of income. Therefore, the creation of Saudi Vision 2030 is to commence the revolution of other sustainable economic resources. One of the sustainable economic resources that Saudi Vision 2030 focuses on is tourism through the creation of tourist attractions, improvement of visiting visa procedures, and development of religious and historical sites (Alshuwaikhat \& Mohammed, 2017). Tourism investment is important for long-run growth, and an essential factor of developing a strategic growth planning process concentrated on income determinants (Du et al., 2016). Tourism and travel create job opportunities and develop trades and booming economy. The World Travel and Tourism Council (2018) reported that the total contribution of the travel and tourism sector to the global GDP and employment growth represents $10.4 \%$ and $9.9 \%$, respectively. The growth of the tourism and travel sector is expected to increase by $11.7 \%$ of the GDP by 2028. Even though the growth of tourism not only reflects positively and directly on industries such as hotels, airlines, and travel agencies but also has a positive indirect contribution to other activi- ties including the restaurant and entertainment industry (World Travel and Tourism Council, 2018). Saudi Arabiais a primary destination for visitors to the holy sites of Makkah and Madinah. Although Saudi Arabia experiences great GDP growth, tourism revenues contribution to the GDP is still low. Tourism in Saudi Arabia needs more development of railway transportation, airlines, accommodations, attractions, entertainment activities, amusement parks and theme parks activities (Ali, 2018). Constructing smart cities along with convenient and high-quality public services would improve the diversification of the GCC economy (Saxena \& AlTamimi, 2018). Tambo (2017) suggested that the promotion and development of tourism and hospitality provided with a high level of quality of infrastructure and services are significant for the satisfaction of tourists and Makkah and Medina visitors. Saudi Arabia aimed that tourism provides up to $10 \%$ of the GDP of Saudi Arabia, but contrasted to just 3\% today (Karantzavelou, 2019). Saudi Arabia presents enormous potential for tourism and entertainment in the region, which is granted with many rich assets. Its demographic, geographic, social, cultural, and economic advantages have allowed it to gain a leading position in the world (Shabir \& Sharma, 2019). The economy of Saudi Arabia is dependent on natural resources, such as petroleum, and oil-based products, which face various challenges during the period of recession, emergency, and oil price shocks in the international market (Waheed et al., 2020). Travel and tourism contribute $10.30 \%$ to the global GDP ( 8 trillion USD), and $3.5 \%$ growth was recorded in 2019 , while the world economy's overall growth rate was $2.5 \%$. There were 330 million jobs provided by the travel and tourism sector, which is accounted for $10 \%$ of the total jobs. Saudi Arabia reported the fastest growing (14\%) economy in travel and tourism GDP in 2019 , while $70 \%$ of the travel and tourism rely on international spending, which is the lowest among the top 20 countries in the world (World Travel \& Tourism Council, 2020). The World Travel \& Tourism Council and the Saudi Commission for Tourism and National Heritage state that the private sector of travel and tourism industry is expected to present Saudi Arabia as a top-five destination, with 100 million domestic and foreign visits by bringing vital domestic and foreign investment and generating a million jobs. The tourism sector is one of the most prominent sectors recognized to diver- 
sify the economy and is the source to attain the Saudi Vision 2030. The number of tourists in Saudi Arabia as Umrah and Hajj pilgrimage performers is increasing every year. As per the Umrah Statistics Bulletin (General Authority for Statistics, 2018), the number of internal Umrah performers was $11,545,497$, while $6,765,614$ external visitors performed Umrah pilgrimage in 2018. As per the Hajj Statistics (General Authority for Statistics, 2019), the number of Hajj performers is also increasing: from $2,371,675$ in 2018 to $2,489,406$ in 2019. Ibrahim et al. (2021) explored the potential of travel and tourism in Saudi Arabia and focused on tourism to diversify the economy. The role of media in the development of tourism is suggested to be backed by the government. In addition, recreational facilities and sports contests should be tourism spots. Alsumairi and Tsui (2017) indicated the importance of low-cost carriers on tourism demand in Saudi Arabia. It was suggested that the increase in capacity of airlines would enhance the number of international tourists in Saudi Arabia. Sherbini et al. (2016) found that tourism is the major source of government income in Saudi Arabia. Dinu (2017) revealed that the travel and tourism industry provides jobs at a local and a worldwide level. Travel and tourism are some of the most income-generating sectors in service industries. Yanet al. (2017) focused on Halal tourism by providing the facilities of Shariah compliance hotels, prayer facilities, and Muslim culture to attract Muslim visitors. The overall development of the tourism industry requires the consideration of Muslim and non-Muslims tourists' priorities and requirements. Hilmi et al. (2020) explained that countries giving preference to low carbon energy sources that affect the economy of oil-exporting nations are forced to search for new avenues to diversify their economy. Jamel (2020) found that tourism positively affects the economic growth of Saudi Arabia. $\mathrm{CO}_{2}$ emissions and financial development are favorable while trade openness is negatively associated with tourism development. However, $\mathrm{CO}_{2}$ emissions, financial development, and trade openness enhance the economic growth and development of Saudi Arabia. Alalmai and Arun (2020) found that religious tourism has a positive effect, while climatic conditions, strict rules for foreign tourists, and lack of information on tourist spots negatively affect Saudi travel and tourism. Diversified tourism packages, advertising of tourist spots, advanced information tech- nology, and infrastructure can enhance tourism in Saudi Arabia. Religious restrictions, perception of international tourists towards Saudi Arabia, and weaker promotion of tourism are the robust barrier in the path of development of Saudi tourism. Triki (2019) suggested the economic growth and development of Saudi Arabia by diversifying the economy and focusing on religious travel and tourism. Given the lack of tourism studies in Saudi Arabia, there is a need to consider the role of the travel and tourism sector in the sustainable economic development of Saudi Arabia. In addition, it is crucial to analyze problems and prospects of Saudi travel and tourism to attain the objective of a thriving economy of Saudi Vision 2030 and enhance the ranking of Saudi travel and tourism universally.

\section{AIM, OBJECTIVES AND HYPOTHESES OF THE STUDY}

The study aims to find out the contribution of the tourism sector in strengthening the Saudi economy to achieve the goals of Saudi Vision 2030. The objectives of the study based on primary and secondary data are as follows:

1. To specify the contribution of tourism revenue to the GDP of Saudi Arabia.

2. To specify the trend of composition and contribution of tourism revenue avenues of Saudi Arabia.

3. To specify tourist satisfaction with tourism services in Saudi Arabia.

\subsection{Hypotheses of the study}

Following are the hypotheses of the study formulated to achieve the objectives of the study:

$H_{0} 1$ : There is no significant and perfect correlation between tourism revenue and the GDP of Saudi Arabia.

$\mathrm{H}_{0}$ 2: There is no difference among the average growth rate of the sources of tourism revenue of Saudi Arabia. 
$\mathrm{H}_{0}$ 3: There is no significant incremental trend of the contribution of all tourism revenue avenues to the GDP of Saudi Arabia.

$H_{0} 4$ : There is no significant dissatisfaction with the essential services and facilities in Saudi Arabia.

$H_{0}$ 5: There is no dissatisfaction with other services and facilities in Saudi Arabia.

\section{METHODOLOGY}

This study is based on primary and secondary data obtained from the Saudi nationals, other residents, and available material on the websites of the General Authority for Statistics of Saudi Arabia, Saudi Arabia Monetary Authority (SAMA) and the World Travel \& Tourism Council. Trend analysis, as well as such statistical tools and techniques like index numbers, correlation, and coefficient variations $(\mathrm{CV})$ were applied to analyze travel and tourism data to obtain the contribution of the travel and tourism sector in the Saudi economy, the composition of tourism revenue, and movement of tourism revenue avenues. An online questionnaire (Appendix B) was distributed and 272 responses were obtained. The results specified the satisfaction of tourists with tourism infrastructure, essential services, and facilities of Saudi Arabia. Percentage and ranks are applied to analyze the collected responses of tourist satisfaction with essential and other services and tourism facilities in Saudi Arabia. In addition, the percentage is applied to analyze the occupancy of transport services and hotels. Following formulas are applied to get the trend $\left(\mathrm{I}_{\mathrm{FB}}\right)$, yearly fluctuations $\left(\mathrm{I}_{\mathrm{CB}}\right)$, average trend growth rate $\left(\mathrm{GR}_{\mathrm{AT}}\right)$, variations among the average trend growth rate $\left(\mathrm{CV}_{\mathrm{ATGR}}\right)$, and tourism revenue avenues weights $\left(\mathrm{W}_{1,2,3, \ldots}\right)$ of tourism data of Saudi Arabia for the period from 2010 to 2018.

Fixed Base Index Numbers $\left(I_{F B}\right)=$ $=\frac{\text { value in current year }}{\text { value in the base year }} \cdot 100$,

Chain Base Index Numbers $\left(I_{C B}\right)=$ $=\frac{\text { value in current year }}{\text { value in the previous year }} \cdot 100$,
Average Trend Growth Rate $\left(G R_{A T}\right)=$

$$
=\frac{(A v \cdot F B I)-100}{A v \cdot F B I} \cdot 100 \text {, }
$$

Coefficient of Variations of ATGR $\left(C V_{A T G R}\right)=$ $=\frac{\text { Standard Deviation of ATGR }}{\text { Mean of ATGR }} \cdot 100$,

Tourism Revenue Avenues Weights $\left(W_{1,2,3, \ldots}\right)=$ $=\frac{\operatorname{TRA}}{\operatorname{TTR} A} \cdot 100$,

TRA and TTRA are tourism revenue avenues and total tourism revenue avenues, respectively.

\subsection{Limitations of the study}

The study is based purely on the primary and secondary data, as well as information taken from the websites, and responses of the Saudi nationals and expats regarding evaluation of the Saudi tourism services and facilities. The primary data applied in the study is only for a limited period (from 2010 to 2018) and the accuracy of the secondary data depends upon the knowledge and experience of the respondents towards Saudi tourism.

\section{DATA INTERPRETATION AND ANALYSIS}

To fulfill the objectives of the study, analysis can be divided into two categories: tourism and the Saudi economy, and tourism satisfaction in Saudi Arabia.

\subsection{Tourism and the Saudi economy}

Saudi Arabia is the fastest-growing travel and tourism sector in the world. The relative study or movement of tourism revenue with the Saudi GDP explains the relative contribution to the economy. The absolute amount of tourism revenue and the GDP of Saudi Arabia are increasing year by year. The tourism revenue of Saudi Arabia and the GDP of Saudi Arabia has increased by $10 \%$ and $49 \%$ approximately (from 2010 to 2018). The increment 
trend of tourism revenue and the GDP of Saudi Arabia explains the lowering of the contribution of tourism revenue to the GDP of Saudi Arabia as it was $5.65 \%$ in 2010 and becomes $4.21 \%$ in 2018 . In 2017, there was a yearly downfall in tourism revenue (92.29) and negative yearly fluctuations in the Saudi GDP in 2015 (86.50) and 2016 (98.57). Therefore, the negative fluctuations in the GDP of Saudi Arabia are not due negativity of the tourism revenue. The correlation between the absolute amounts of tourism revenue and the GDP of Saudi Arabia is positive but not perfect $(r=-0.32)$ for the period from 2010 to 2018. This reveals that tourism revenue affects the GDP positively but not perfectly. The yearly contribution of the tourism revenue to the GDP of Saudi Arabia is only 5.65\% comparing to $4.21 \%$ for the period from 2010 to 2018. It means some other sectors contribute more than the tourism revenue and enhance the GDP of Saudi Arabia. The contribution of tourism revenue to the GDP of Saudi Arabia is decreasing every year since 2010 (Appendix A, Table A1). Thus, there is no perfect correlation between tourism revenue and the GDP of Saudi Arabia. Hence, $H_{0} 1$ is accepted.

The composition and weight trend of sources of tourism revenue explain the importance of individual sources of tourism revenue and their comparative trend. Accommodation for visitors (21.54\%), food and beverages services (33.59\%), air transportation $(26.98 \%)$ are the most contributing avenues in tourism revenues in Saudi Arabia, while railway transportation $(0.18 \%)$, water transportation $(0.02 \%)$, and cultural activities $(0.48 \%)$ have very low average contribution or weights in total tourism revenue. The average trend of the growth rate of the sources of tourism revenue of Saudi Arabia is significantly different as the coefficient of variation (1.86) is above 1 . There is a significant difference among the average growth rate of the sources of tourism revenue of Saudi Arabia. The average trend of growth rate $\left(\mathrm{GR}_{\mathrm{AT}}\right)$ of most contributing avenues either negative (accommodation for visitors $=-14.15$ ) or very low (food and beverage services $=1.51$, air passenger transport $=0.18$ ). Hence, $\mathrm{H}_{0} 2$ is rejected. The overall revenue of the tourism sector of Saudi Arabia is in decline trend as it was 100 (assumed) in 2016 comparing to 92 and 96 in 2017 and 2018 respectively (Appendix A, Table A2). Accommodation for visitors, food and beverages activities, and air transportation are the main sources of income for the tourism sector of Saudi Arabia. Railway transportation, water transportation, cultural activities, other special tourism services, and sports and recreational activities are the least revenue generated services in Saudi tourism. Hence, fluctuations in the accommodation, food and beverages services, and air transportation affect the revenues of the tourism sector of Saudi Arabia (Appendix A, Table A2).

The contribution trend of tourism revenue avenues to the GDP of Saudi Arabia explains the degree and direction of the individual tourism revenue avenues to the GDP. The growth trend of the major contributors to tourism revenue i.e., accommodation for visitors (1.04\% of GDP), food and beverages services (1.57\% of GDP), air transportation (1.27 $\%$ of GDP) is $-17.44,-1.41$, and 2.79 , respectively. Small contributors $(\leq 0.25 \%$ of GDP) i.e., sports and recreational activities (12.76\%) and other specific tourism services (11.31\%) contribute positively (Appendix A, Table A3). The average growth trend of sports and recreational activities and other specific tourism services is not affecting the GDP positively because its average contribution to GDP is $0.12 \%$ and $0.03 \%$ only. Therefore, there is no significant incremental trend of the contribution of all tourism revenue avenues to the GDP of Saudi Arabia. Hence, $\mathrm{H}_{0} 3$ is accepted. There is a proportionate decrement in the contribution of total tourism revenue to GDP seen in previous years. The contribution of tourism revenue to GDP was $5.32 \%, 4.60 \%$, and $4.21 \%$ in 2016, 2017, and 2018 respectively. As per data of the General Authority for Statistics (2018), the local passenger transport services $(64.02 \%)$ are lesser utilized than the international passenger services (80.25\%) in Saudi Arabia. The transportation and residential facilities also play a vital role in the growth and development of the travel and tourism of a nation. The transportation and residential facilities of Saudi Arabia are not fully occupied. In local transport services, land transportation occupied capacity (60.61\%) and air transportation occupied capacity $(64.76 \%)$ is lesser occupied than the capacity of the railway $(91.67 \%)$ and water transportation (85.71\%) (Appendix A, Table A4). The room occupancy in Saudi Arabia is enhancing but still below $70 \%$ of the total capacity for the period from 2010 to 2018 (Appendix A, Table A5). 


\subsection{Tourist satisfaction in Saudi Arabia}

Tourist satisfaction refers to the satisfaction of tourists in the context of tourism infrastructure, services, etc., of a particular place, territory, or nation. The overall satisfaction can be divided into i.e. essential services and facilities, and other services and factors.

Essential services and facilities refer to food, health, residential, emergency, safety and security, cleanness of tourist spots, washroom and toilet facilities, communication (mobile and internet), transportation facilities at tourist spots. Based on tourism satisfaction in Saudi Arabia, 29\%, 37\%, and $23 \%$ of tourists are strongly satisfied, satisfied, and neutral, while $8 \%$ and $3 \%$ of tourists are dissatisfied and strongly dissatisfied with essential services and facilities of Saudi tourism. The rank analysis of tourists' responses regarding essential services and facilities reveals that the overall rank of the satisfied, strongly satisfied, and neutral opinions is 1,2 , and 3 respectively, while 4 and 5 are dissatisfied and strongly dissatisfied. In Saudi Arabia, $66 \%$ of tourists are either strongly satisfied or satisfied, and $23 \%$ have neutral opinions about essential services and facilities of tourism (Appendix A, Table A6). Thus, there is no significant dissatisfaction among tourists regarding the essential services and facilities of tourism in Saudi Arabia. Hence, HO4 is accepted. In general, there should be efforts to convert all the neutral, dissatisfied, and strongly dissatisfied tourists into satisfied or strongly satisfied by providing better food (26\% neutral), transportation ( $25 \%$ neutral), and cleanness of tourist spots (24\% neutral). Neutral tourists should be made satisfied or strongly satisfied. Washroom and toilet facilities (12\% dissatisfied and $7 \%$ strongly dissatisfied) and cleanness of tourist spots (11\% dissatisfied and 5\% strongly dissatisfied) should be facilitated. Satisfied tourists i.e., strongly satisfied and satisfied tourists have a negative opinion on residential services, washroom and toilet facilities, mobile, and internet, transportation, and cleanness of tourist spots (Appendix A, Table A6).

Other services, facilities, and factors comprise beauty and pleasing services; shopping, sports, and recreation, relaxation facilities; attitude or be- havior of residents, tourist guides and tourism information, nightlife, presence of hawkers and beggars, etc. Based on tourism satisfaction in Saudi Arabia, $28 \%, 36 \%$, and $25 \%$ of tourists are strongly satisfied, satisfied, and neutral, while $7 \%$ and $4 \%$ of tourists are dissatisfied and strongly dissatisfied with other services and facilities of Saudi tourism. The rank analysis of the tourists' responses regarding other services and facilities reveals that the overall rank of the satisfied, strongly satisfied, and neutral tourists is 1,2 , and 3 respectively, while 4 and 5 are dissatisfied and strongly dissatisfied tourists. In Saudi Arabia, $64 \%$ of tourists are either strongly satisfied or satisfied, and $25 \%$ have neutral opinions about other services and facilities of tourism (Appendix A, Table A7). Therefore, there is no significant dissatisfaction with essential services and facilities of tourism in Saudi Arabia. Hence, $H_{0} 5$ is accepted. Overall, there should be efforts to convert neutral (25\%), dissatisfied (7\%), and strongly dissatisfied (4\%) into satisfied or strongly satisfied tourists by providing guides and tourism information ( $31 \%$ neutral), beauty and pleasing services (27\% neutral), sports and recreational facilities (26\% neutral), better nightlife (8\% dissatisfied), and touristic spots free from the hawkers and beggars (8.5\% dissatisfied). Tourists in Saudi Arabia are strongly dissatisfied with the presence of beggars and hawkers at tourist spots. Satisfied tourists i.e., strongly satisfied and satisfied tourists have negative opinions about beauty and pleasing services, shopping facilities, tourist guides, and tourism information (Appendix A, Table A7).

\section{RESULTS}

There is a positive but low degree $(r=0.32)$ correlation between tourism revenue and the GDP of Saudi Arabia. Short-term or yearly fluctuations reveal the negativity $(r=-0.08)$ between the tourism revenue and the Saudi GDP. The absolute amount of tourism revenue and the GDP of Saudi Arabia are increasing year by year. The tourism revenue of Saudi Arabia and the GDP of Saudi Arabia has increased by $10 \%$ and $49 \%$ approximately (from 2010 to 2018) (Appendix A, Table A1). Movement of tourism revenue and the GDP analysis refers to an increment of absolute tourism contribution in the Saudi GDP while losing in a proportionate con- 
tribution. The average growth rate of major sources of tourism revenue either negative (accommodation $=-14.15 \%$ ) or growth rate is very low (food and beverages services $=1.51 \%$; and air transportation $=0.18 \%)$. Overall, there is negativity $(-4.32 \%)$ in the tourism revenue avenues (Appendix A, Table A2). All the negative growing trend tourism revenues are related to either hotel facilities, transportation, or other special tourism services. The growth trend of the major contributors to tourism revenue i.e.,accommodation for visitors $(1.04 \%$ of the GDP), food and beverages services (1.57\% of the GDP), air transportation (1.27 \% of the GDP) is $-17.44,-1.41$, and -2.79 , respectively. Small contributors $(\leq 0.25 \%$ of the GDP) i.e., sports and recreational activities (12.76\%) and other specific tourism services (11.31\%) contribute positively but affect the GDP negligibly (Appendix A, Table A3). The passenger transport services, hotel, and associated facilities contribution trend are negative in Saudi Arabia. Passenger transport services in Saudi Arabia are not fully occupied (64.02\%) (Appendix A, Table A4) and the hotel occupancy is below 70\% (from 2010 to 2018) (Appendix A, Table A5). The survey on the satisfaction of tourists reveals that $29 \%, 37 \%$, and $23 \%$ of tourists are strongly satisfied and satisfied, while $8 \%$ and $3 \%$ of tourists are dissatisfied and strongly dissatisfied with the essential services of Saudi tourism. The overall rank of the satisfied, strongly satisfied, and neutral tourists regarding the essential tourism services and facilities are 1,2, and 3 respectively, while 4 and 5 are dissatisfied and strongly dissatisfied tourists. In Saudi Arabia, 66\% of tourists are either strongly satisfied or satisfied, and 23\% have neutral opinions about essential tourism services and facilities (Appendix A, Table A6). In Saudi Arabia, $28 \%, 36 \%$, and $25 \%$ of tourists are strongly satisfied, satisfied, and neutral, while $7 \%$ and $4 \%$ of tourists are dissatisfied and strongly dissatisfied with other services and facilities of Saudi tourism. The overall rank of the satisfied, strongly satisfied, and neutral tourists regarding other tourism services and facilities is 1,2 , and 3 respectively, while 4 and 5 are dissatisfied and strongly dissatisfied tourists. In Saudi Arabia, $64 \%$ of tourists are either strongly satisfied or satisfied and $25 \%$ have neutral opinions about essential services and facilities of tourism (Appendix A, Table A7). There is negativity seen in the accommodation facilities and their level of services, and transportation facilities and their services. In Saudi Arabia, tourists are dissatisfied with residential services, washrooms and toilets, mobile and internet, transportation, and the cleanness of tourist spots. Viewing tourist satisfaction regarding other facilities related to Saudi tourism, the level of beauty and pleasing services, shopping facilities, availability of tourist guide services is low. Hawkers and beggars are also a considerable problem for tourists in Saudi Arabia.

\section{DISCUSSION}

Religious holy visits of Hajj and Umrah are the main reason for national and international tourists to visit Saudi Arabia. Damanhouri (2017) revealed that tourists visit Saudi Arabia for social and cultural aspects. Visitors from all around the world come to Saudi Arabia to perform Hajj and Umrah pilgrimages every year. So, the holy cities of Makkah and Madinah are the most visited places in Saudi Arabia. In Saudi Arabia, tourism revenue is increasing absolutely but lowering its contribution proportionately in the GDP (average growth of contribution of tourism revenue to the GDP is $-4.32 \%$ for the period from 2016 to 2018). It indicates that the Saudi GDP is enhancing its level more than the level of tourism revenue. The major contribution to average growth is very low and not satisfactory i.e. accommodation/hotel services $(-17.44 \%)$, food and beverage services $(-1.41 \%)$, and air transportation $(-2.79 \%)$. Thus, hotel services and the air transportation are the main avenues of consideration to enhance the contribution of tourism revenue to the GDP of Saudi Arabia. Transport services of Saudi Arabia are not utilizing their full capacity (international passenger capacity $-80.25 \%$, local passenger capacity $-64.02 \%)$. In the local travel context, national air transportation (64.76\%) and local land transportation (60.61\%) are the least utilized options for transportations in Saudi Arabia. Ali (2018), and Alsumairi and Tsui (2017) indicated the importance of low-cost transportation/ carriers and suggested the enhancements of the airline capacity in Saudi Arabia. Due to the unavailability of expected services of the tourists, the occupancy rate of the hotel rooms is approximately below $70 \%$ since the last decade. Yusuf (2014) stated that the Middle East is the most 
underdeveloped tourism place in the world. Abuhjeeleh (2019) revealed that many places in Saudi Arabia are undiscovered and undisclosed. Air and road transportation can start to explore the undisclosed places and make them easily reachable for tourists. In Saudi Arabia, worldclass residential facilities, food and beverages facilities, and safety and security can enhance satisfaction and attract more tourists. It will also enhance the revenue of Saudi Arabia. Saudi government can study the constraints of air transportation and the reasons responsible for the low air and land transportation rate to enhance their impact on the tourism revenue of Saudi Arabia. Sport and recreational activities, and other specific tourism services are the fastest growing avenues of Saudi tourism. In Saudi Arabia, the satisfaction of most tourists is above the average. However, the satisfied customers have problems related to services i.e. residential services, washroom and toilet facilities, mo- bile and internet, transportation, and cleanness of touristspots. The cleanness of tourist spots, and washroom and toilet facilities are also the highlighting factors to enhance the level of satisfaction. Other services, facilities, and other tourism-related factors affect tourism negatively i.e. beauty and pleasing services, shopping facilities, tourist guides, and tourism information. Alalmai and Arun (2020) found that lack of information on tourist spots negatively affects Saudi travel and tourism. In addition, hawkers and beggars are the factor that affects the tourists at tourist spots. Food and accommodation facilities, the need and requirement of tourists regarding the transport services are considered to enhance the contribution of overall tourism revenue in the Saudi economy. Alshuwaikhat and Mohammed (2017) stated that tourist attractions, simple visiting visa procedures, and the development of religious and historical sites enhance tourism revenue.

\section{CONCLUSION}

The study focused and outlined the trend of composition and contribution of tourism revenue to the GDP of Saudi Arabia, and tourist satisfaction with essential and other services and tourism infrastructure in Saudi Arabia in attaining the objectives of Saudi Vision 2030. The tourism revenue of Saudi Arabia enhances absolutely but is not proportional to the GDP. The growth of major contributors of tourism revenue is either low or negative i.e. accommodation, food and beverages services, and air transportation. The contribution of accommodation, food and beverages services, air transportation, and railway transportation is negative due to the low enhancement of absolute amount comparatively to the GDP in Saudi Arabia. In general, tourists in Saudi Arabia are either strongly satisfied or satisfied with the essential services and facilities of tourism. Only residential facilities and safety and security are the services that lower the satisfaction of tourists. Dissatisfied and strongly dissatisfied tourists' proportion is negligible and very low in Saudi Arabia. In addition, regarding other services and facilities, tourists in Saudi Arabia are either strongly satisfied or satisfied. Only shopping facilities, tourist guides, and tourism information are the services that lower the satisfaction of tourists. Saudi government can take some steps to provide excellent residential, accommodation, and food services to boost the level of tourist satisfaction. In its turn, it will also enhance the level of international air transportation, local land transportation, and utilize the capacity of hotel occupancy. It is essential to enhance the satisfaction of tourists with washroom and toilet facilities, mobile and internet, transportation, and cleanness of tourist spots. Beauty and pleasing services, shopping facilities, tourist guides, and tourism information are the other factors that attract and enhance the satisfaction of tourists. Tourist spots must be free from beggars and hawkers who create the nuisance in the leisure of tourists. Additionally, to achieve the objective of the thriving economy of Saudi Vision 2030 and to attract more tourists, the government may focus on providing a variety of services as per the economic level of the targeted tourists, and soften visiting visa procedures and fees. Limited availability of primary data regarding travel and tourism of Saudi Arabia and unwilling responses of some respondents are the limitations of the study. There is further research scope available in the Saudi tourism sector based on the contribution of inbound and outbound tourism in the Saudi economy. 


\section{AUTHOR CONTRIBUTIONS}

Conceptualization: Anis Ali.

Data curation: Anis Ali.

Formal analysis: Anis Ali.

Funding acquisition: Anis Ali.

Investigation: Anas A. Salameh.

Methodology: Anis Ali.

Project administration: Anis Ali.

Software: Anas A. Salameh.

Supervision: Anas A. Salameh.

Validation: Anis Ali.

Visualization: Anas A. Salameh.

Writing - original draft: Anis Ali.

Writing - review \& editing: Anis Ali.

\section{ACKNOWLEDGMENT}

The authors would like to thank the Deanship of Scientific Research, Prince Sattam Bin Abdulaziz University, Alkharj, Saudi Arabia, for providing financial support to complete this project (Project No: 2020/02/16978).

\section{REFERENCES}

1. Abuhjeeleh, M. (2019). Rethinking tourism in Saudi Arabia: Royal vision 2030 perspective. African Journal of Hospitality, Tourism and Leisure, 8(5), 1-16. https://www.ajhtl.com/uploads/7/1/6/3/7163688/article_37_ vol_8_5_2019_jordan.pdf

2. Alalmai, A. A., \& Arun, A. (2020). The Strength, Weakness, Opportunity and Threat Level in Tourism Relations between India and Saudi Arabia. TEST Engineering and Management, 82, 7742-7747. Retrieved from https://www.researchgate.net/ publication/339301620_The_ Strength_Weakness_Opportunity_and_Threat_Level_in_Tourism_Relations_between_India_ and_Saudi_Arabia

3. Ali, A. (2018). Travel and tourism: growth potentials and contribution to the GDP of Saudi Arabia. Problems and Perspective in Management, 16(1), 417427. https://doi.org/10.21511/ ppm.16(1).2018.39

4. Al-Kibsi, G., Woetzel, J., Isherwood, T., Khan, J., Mischke, J., \&
Noura, H. (2015). Moving Saudi Arabia's economy beyond oil. Mc Kinsey \& Company. Retrieved from https://www.mckinsey.com

5. Alshuwaikhat, H. M., \& Mohammed, I. (2017). Sustainability matters in national development visions - Evidence from Saudi Arabia's Vision for 2030. Sustainability, 9(3), 408. https://doi. org/10.3390/su9030408

6. Alsumairi, M., \& Tsui, K. W. H. (2017). A case study: The impact of low-cost carriers on inbound tourism of Saudi Arabia. Journal of Air Transport Management, 62, 129-145. https://doi.org/10.1016/j. jairtraman.2017.04.001

7. Damanhouri, A. M. S. (2017). Study of the Social and Cultural Aspects of Saudi Tourists and Evaluate the Services Provided to Tourist of Saudi - An Applied Study for the Tourism Sector in The Kingdom of Saudi Arabia. International Business Research, 10(1), 153-162. https://doi. org/10.5539/ibr.v10n1p153

8. Dinu, A. M. (2017). The importance of tourism and touristic services in GDP. Quaestus, 10, 73-80. Retrieved from https:// www.quaestus.ro/wp-content/uploads/2012/03/Ana-Maria-DINU. pdf

9. Du, D., Lew, A. A., \& Ng, P. T. (2016). Tourism and economic growth. Journal of Travel Research, 55(4), 454-464. https://doi.org /10.1177\%2F0047287514563167

10. Esmail, H. (2018). Economic growth of Saudi Arabia between present and future according to 2030 vision. Asian Social Science, 14(12), 192-201. https://doi. org/10.5539/ass.v14n12p192

11. General Authority for Statistics (2019). Hajj Statistics 2019-1440. Retrieved from https://www.stats. gov.sa/sites/default/files/haj_40_ en.pdf

12. General Authority for Statistics (2018). Umrah Statistics Bulletin. Retrieved from https://www.stats. gov.sa/sites/default/files/umrah_ statistics_bulletin_2018_en.pdf

13. Hilmi, N., Farahmand, S., \& Belaid, F. (2020). Why Should Saudi Arabia Diversify Its Economy? In 
Economic Development in the Gulf Cooperation Council Countries (pp. 89-109). Singapore: Springer.

14. Ibrahim, A. O., Baqawy, G. A., \& Mohamed, M. A. S. (2021). Tourism attraction sites: Boasting the booming tourism of Saudi Arabia. International Journal of Advanced and Applied Sciences, 8(4), 1-11. https://doi.org/10.21833/ ijaas.2021.04.001

15. Jamel, L. (2020). The Relation between Tourism and Economic Growth: A Case of Saudi Arabia as an Emerging Tourism Destination. Virtual Economics, 3(4), 29-47. https://doi.org/10.34021/ ve.2020.03.04(2)

16. Karantzavelou, V. (2019).Vision 2030 Plan aims to make Saudi Arabia a top five global destination. Travel Daily News. Retrieved from https://www.traveldailynews.com/ post/vision-2030-plan-aims-tomake-saudi-arabia-a-top-fiveglobal-destination

17. Khan, F., \& Callanan, M. (2017) The "Halalification" of tourism. Journal of Islamic Marketing, 8(4), 558-577. https://doi.org/10.1108/ JIMA-01-2016-0001

18. Khan, M. (2016). Saudi Arabia’s vision 2030. Defence Journal, 19(11), 36-42. https://www.proquest.com/ docview/1803047698/fulltextPDF/5AAE7A84C3AD4939PQ/1?accountid $=137403$

19. Khan, S., \& Alam, M. S. (2014). Kingdom of Saudi Arabia: A potential destination for medical tourism. Journal of Taibah University Medical Sciences, 9(4), 257-262. https://doi.org/10.1016/j. jtumed.2014.01.007

20. Mahroum, S., \& Al-Saleh, Y. (2016). Economic diversification policies in natural resource rich economies ( $1^{\text {st }}$ ed.). New York: Routledge.

21. Mansour, M., \& Mumuni, A. G. (2019). Motivations and attitudes toward domestic tourism in Saudi Arabia. European Journal of Tourism, Hospitality and Recreation, 9(1), 27-37. https://doi. org/10.2478/ejthr-2019-0004

22. Ministry of Tourism of Saudi Arabia (2020). Tourism Investment. Retrieved from https://mt.gov.sa/
en/TourismInvestment/Pages/

TourismInvestment.aspx

23. Monshi, E., \& Scott, N. (2017).3: Developing event tourism in Saudi Arabia: Opportunities and Challenges. In H. Almuhrzi, H. Alriyami \& N. Scott (Eds.), Tourism in the Arab World: An industry perspective (pp.38-55). Bristol: Channel View Publications. https://doi. org/10.21832/9781845416157-004

24. SAMA (2020). Yearly Statistics: Annual Statistics 2020. Retrieved from https://www.sama.gov.sa/ en-US/EconomicReports/Pages/ YearlyStatistics.aspx

25. Saxena, S., \& Al-Tamimi, T. A. S. M. (2018). Visioning "smart city" across the Gulf Cooperation Council (GCC) countries. Foresight, 20(3), 237-251. https://doi. org/10.1108/FS-11-2017-0068

26. Shabir, S., \& Sharma, R. (2019). Role of soft skills in tourism industry in Saudi Arabia. International Journal of Engineering and Management Research, 8792. https://doi.org/10.31033/ ijemr.9.4.14

27. Sherbini, A., Aziz, Y. A., Sidin, S. M., \& Yusof, R. N. R. (2016). Income diversification for future stable economy in Saudi Arabia: An overview of tourism industry. International Journal of Economics, Commerce and Management, 6(11), 173-189. Retrieved from http://psasir.upm.edu.my/id/ eprint/54545/

28. Statista (2020). Occupancy rate of rooms in hotels and similar accommodation establishments in Saudi Arabia from 2008 to 2018 (Report). Retrieved from https://www. statista.com/statistics/1011042/ hotel-room-occupancy-rate-saudi-arabia/\#: :text

29. Tambo, E. (2017). Smart positioning of tourism and hospitality industry model in economic transformation in Saudi Arabia. Journal of Tourism and Hospitality, 15(1), 82-96. Retrieved from https://www.researchgate.net/ publication/317349217_Smart_ positioning_of_tourism_and_hospitality_industry_model_in_economic_transformation_in_Saudi_Arabia
30. Triki, B. T. (2019). The role of religious tourism in sustainable development in Saudi Arabia: evidence from quantile non-causality test. GeoJournal of Tourism and Geosites, 27(4), 1321-1333. Retrieved from http://gtg.webhost. uoradea.ro/PDF/GTG-4-2019/ gtg.27417-436.pdf

31. Waheed, R., Sarwar, S., \& Dignah, A. (2020). The role of non-oil exports, tourism and renewable energy to achieve sustainable economic growth: What we learn from the experience of Saudi Arabia. Structural Change and Economic Dynamics, 55, 49-58. https://doi.org/10.1016/j.strueco.2020.06.005

32. World Travel and Tourism Council (2020). Travel \& Tourism: Global economic impact \& trends 2020 (Report). Retrieved from https:// wttc.org/Portals/0/Documents/ Reports/2020/Global\%20Economic\%20Impact\%20Trends\%202020. pdf?ver $=2021-02-25-183118-360$

33. World Travel and Tourism Council (2018). Travele Tourism Economic Impact, Issues 2018. Retrieved from https://dossierturismo.files.wordpress.com/2018/03/ wttc-global-economic-impactand-issues-2018-eng.pdf

34. Yan, L. S., Zahari, N. A., Ismail, A. S., \& Zain, N. M. (2017). Halal tourism: A new world for tourism industry. International Journal of Asian Social Science, 7(8), 643-657. Retrieved from https://ideas.repec. org/a/asi/ijoass/2017p643-657. html

35. Yusuf, N. (2014). Tourism development in Saudi Arabia. Journal of Business and Retail Management Research, 8(2), 65-70. Retrieved from https:// www.pif.gov.sa/en/Pages/publicinvestmentfundprogram. aspx?gclid=EAIaIQobChMIo-Txn6aQ8QIVj9iyCh0JIghEEAAYASAAEgJkjvD_BwE\#6 


\section{APPENDIX A}

Table A1. Revenue and its contribution to the GDP and relative movement (million Riyals)

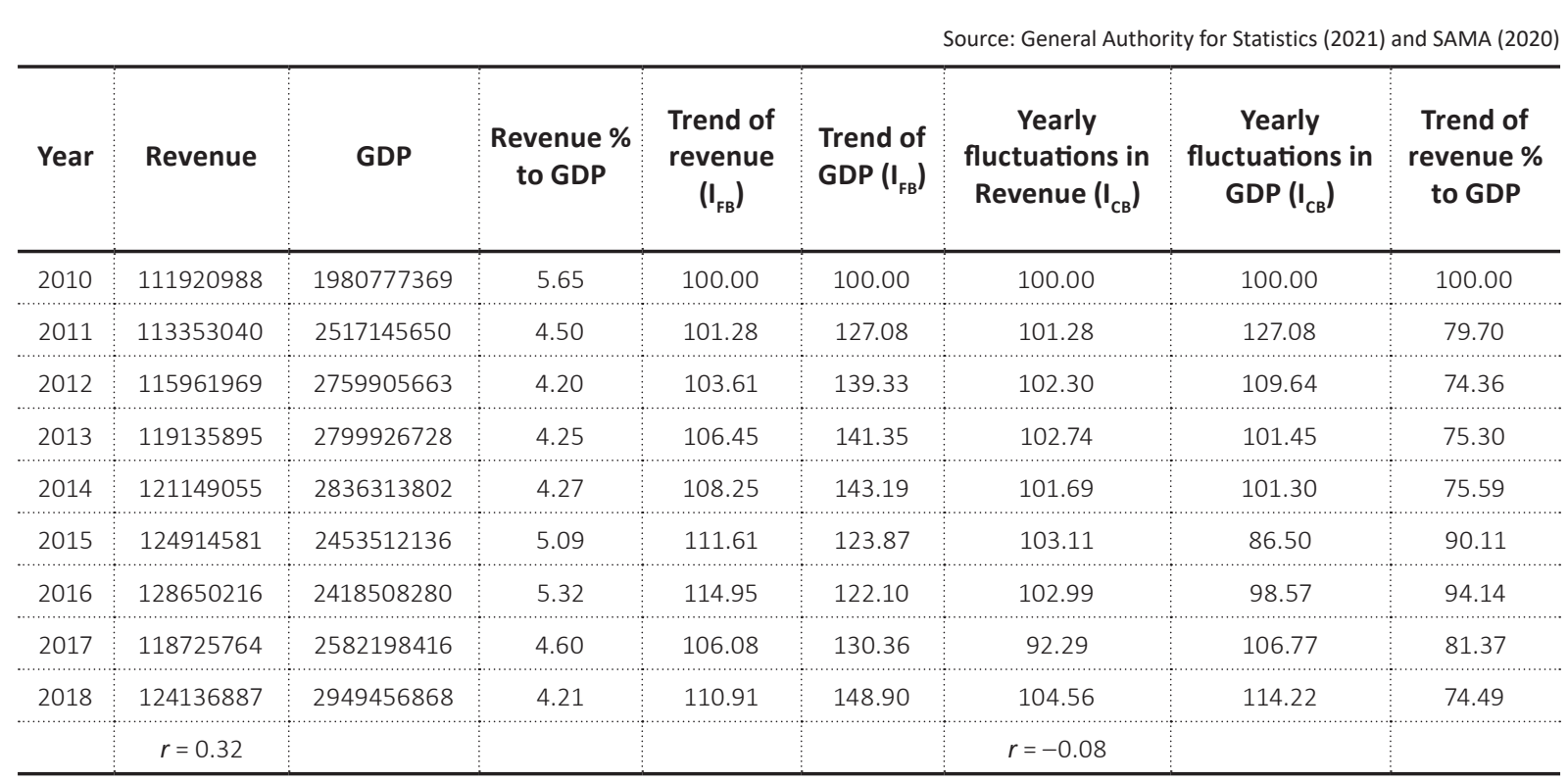

Note: GDP at producers' value and at current price.

Table A2. Weights and composition trend of tourism revenue in Saudi Arabia (million Riyals)




Table A3. Contribution trend of tourism revenue avenues to GDP of Saudi Arabia (million Riyals)

\begin{tabular}{|c|c|c|c|c|c|c|c|c|c|}
\hline & & & & & & Source: Gen & neral Author & rity for Statis & istics (2021) \\
\hline No. & Economic activity & 2016 & $\begin{array}{l}\% \text { Contr. } \\
\text { To GDP }\end{array}$ & 2017 & $\begin{array}{l}\text { \% Contr. } \\
\text { To GDP }\end{array}$ & 2018 & $\begin{array}{l}\% \text { Contr } \\
\text { To GDP }\end{array}$ & $\begin{array}{l}\text { Av. of } \\
\% \text { Contr } \\
\text { To GDP }\end{array}$ & $\begin{array}{c}\text { Av. } \\
\text { Growth } \\
\text { contr. } \\
\text { To GDP }\end{array}$ \\
\hline 1 & Accommodation & 38282356 & 1.58 & 20596450 & 0.8 & 21741578 & 0.74 & 1.04 & -17.44 \\
\hline 2 & Food and beverage services & 39657622 & 1.64 & 41511456 & 1.61 & 43441046 & 1.47 & 1.57 & -1.41 \\
\hline 3 & Railway transportation & 217236 & 0.01 & 227842 & 0.01 & 238077 & 0.01 & 0.01 & -1.38 \\
\hline 4 & Road transportation & 3171309 & 0.13 & 4260046 & 0.16 & 4507727 & 0.15 & 0.15 & 4.13 \\
\hline 5 & Water transportation & 19731 & 0 & 24617 & 0 & 26155 & 0 & 0.00 & 2.62 \\
\hline 6 & Air transportation & 33202048 & 1.37 & 32787596 & 1.27 & 34143347 & 1.16 & 1.27 & -2.79 \\
\hline 7 & Rent of transport & 5894438 & 0.24 & 6919160 & 0.27 & 7233393 & 0.25 & 0.25 & 1.13 \\
\hline 8 & $\begin{array}{l}\text { Transport agencies and } \\
\text { reservation services }\end{array}$ & 5498805 & 0.23 & 7037524 & 0.27 & 7236799 & 0.25 & 0.25 & 2.83 \\
\hline 9 & Cultural activities & 481391 & 0.02 & 628313 & 0.02 & 657880 & 0.02 & 0.02 & 3.42 \\
\hline 10 & Sport and recreation activities & 1817546 & 0.08 & 3930445 & 0.15 & 4065610 & 0.14 & 0.12 & 12.76 \\
\hline 11 & Other specific touristic services & 407734 & 0.02 & 802316 & 0.03 & 845275 & 0.03 & 0.03 & 11.32 \\
\hline Total & tourism revenue & 128650216 & 5.32 & 118725764 & 4.6 & 124136887 & 4.21 & & -4.32 \\
\hline GDP & & 2418508280 & 100 & 2582198416 & 100 & 2949456868 & 100 & & \\
\hline
\end{tabular}

Table A4. Transport services in Saudi Arabia

Source: General Authority for Statistics (2018).

\begin{tabular}{|c|c|c|c|c|c|c|c|}
\hline No. & Transport services & $\begin{array}{l}\text { Number of } \\
\text { available } \\
\text { seats for } \\
\text { international } \\
\text { flights }\end{array}$ & $\begin{array}{c}\text { Number of } \\
\text { international } \\
\text { passengers }\end{array}$ & $\begin{array}{l}\text { Operating } \\
\text { rate of } \\
\text { international } \\
\text { flights (\%) }\end{array}$ & $\begin{array}{l}\text { Number of } \\
\text { available } \\
\text { seats for } \\
\text { local flights }\end{array}$ & $\begin{array}{c}\text { Number } \\
\text { of local } \\
\text { passengers }\end{array}$ & $\begin{array}{c}\text { Operating } \\
\text { rate of local } \\
\text { flights (\%) }\end{array}$ \\
\hline 1 & Railway & - & - & - & 2400123 & 2223143 & 91.67 \\
\hline 2 & Land & 6014235 & 5142114 & 84.86 & 42459533 & 25725836 & 60.61 \\
\hline 3 & Water & 911422 & 855100 & 88.89 & 700565 & 633788 & 85.71 \\
\hline \multirow[t]{2}{*}{4} & Air & 61024545 & 48532146 & 79.48 & 75265744 & 48765890 & 64.76 \\
\hline & Total & 67950202 & 54529360 & 80.25 & 120825965 & 77348657 & 64.02 \\
\hline
\end{tabular}

Table A5. Hotel room occupancy in Saudi Arabia

Source: Statista (2020)

\begin{tabular}{c|c|c|c|c|c|c|c|c|c|c|c|c|c|c|c|c|}
\hline Year & $\mathbf{2 0 1 0}$ & $\mathbf{2 0 1 1}$ & $\mathbf{2 0 1 2}$ & $\mathbf{2 0 1 3}$ & $\mathbf{2 0 1 4}$ & $\mathbf{2 0 1 5}$ & $\mathbf{2 0 1 6}$ & $\mathbf{2 0 1 7}$ & $\mathbf{2 0 1 8}$ \\
\hline Room occupancy ratio (\%) & 59.2 & 63 & 64 & 65.2 & 66 & 67 & 68 & 64 & 66.6 \\
\hline
\end{tabular}


Table A6. Tourists' responses about essential services and facilities of Saudi Arabian tourism

\begin{tabular}{|c|c|c|c|c|c|c|}
\hline No. & Variables & $\begin{array}{c}\text { Strongly } \\
\text { satisfied } \\
\text { (Rank) }\end{array}$ & $\begin{array}{l}\text { Satisfied } \\
\text { (Rank) }\end{array}$ & $\begin{array}{c}\text { Neutral } \\
\text { (Rank) }\end{array}$ & $\begin{array}{l}\text { Dissatisfied } \\
\text { (Rank) }\end{array}$ & $\begin{array}{c}\text { Strongly dissatisfied } \\
\text { (Rank) }\end{array}$ \\
\hline 1 & Food services & $78(2)$ & $102(1)$ & $70(3)$ & $15(4)$ & $7(5)$ \\
\hline 2 & Health services & $78(2)$ & $114(1)$ & $54(3)$ & $16(4)$ & $10(5)$ \\
\hline 3 & Residential services & $69(3)$ & $103(1)$ & $76(2)$ & $19(4)$ & $5(5)$ \\
\hline 4 & Emergency services & $85(2)$ & $111(1)$ & $54(3)$ & $15(4)$ & $7(5)$ \\
\hline 5 & $\begin{array}{l}\text { Safety and security } \\
\text { services }\end{array}$ & $117(1)$ & $82(2)$ & $49(3)$ & $19(4)$ & $5(5)$ \\
\hline 6 & Washroom and toilet & $66(2)$ & $92(1)$ & $63(3)$ & $33(4)$ & $18(5)$ \\
\hline 7 & Mobile and internet & $76(2)$ & $104(1)$ & $59(3)$ & $20(4)$ & $13(5)$ \\
\hline 8 & Transportation & $72(2)$ & $106(1)$ & $68(3)$ & $19(4)$ & $7(5)$ \\
\hline \multirow[t]{2}{*}{9} & $\begin{array}{l}\text { Touristic spots } \\
\text { cleanness }\end{array}$ & $70(2)$ & $95(1)$ & $65(3)$ & $29(4)$ & $13(5)$ \\
\hline & $\begin{array}{l}\text { Average/Rank/ } \\
\text { Percentage }\end{array}$ & 79 (2) $29 \%$ & 101(1) 37\% & 62 (3) $23 \%$ & $21(4) 8 \%$ & $9(5) 3 \%$ \\
\hline
\end{tabular}

Table A7. Tourists' responses about other services, facilities and related factors of Saudi Arabian tourism

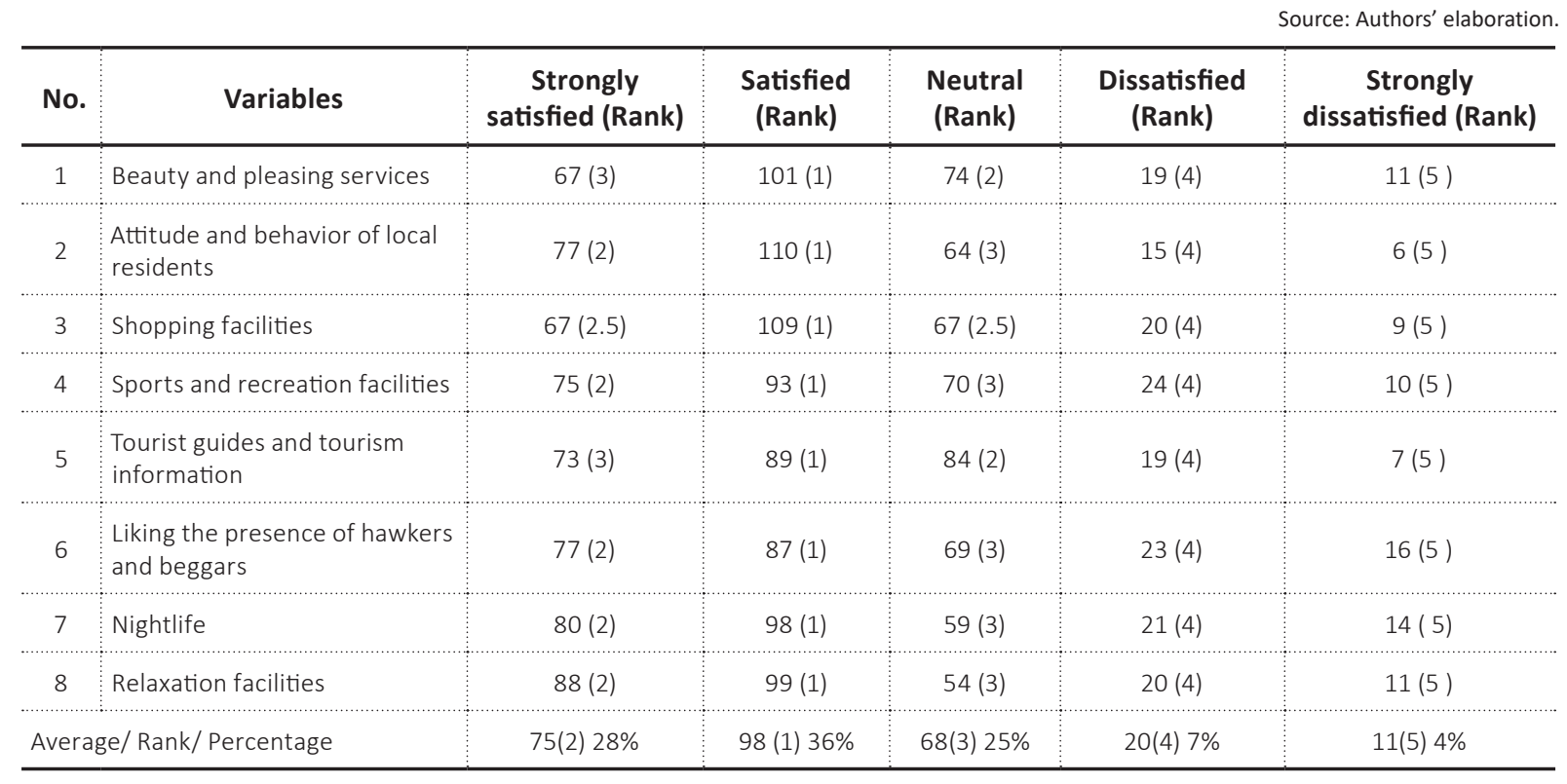




\section{APPENDIX B. QUESTIONNAIRE ON ESSENTIAL AND OTHER TOURISM SERVICES AND FACILITIES IN SAUDI ARABIA}

\section{Respected respondents,}

The following questions are designed to fulfill the objectives of the study about the tourist satisfaction with TOURISM services available in Saudi Arabia. The responses will be analyzed for study purposes only. Please, give your responses (1 to 5) for:

\section{Strongly Agree $=1$, Agree $=2$, Neutral $=3$, Disagree $=4$, Strongly Disagree $=5$}

\begin{tabular}{l}
\hline \multicolumn{1}{c}{ Variables (Services) } \\
\hline I am satisfied with food services during travel. \\
I am satisfied with health services during travel. \\
I am satisfied with residential / accommodation services during travel. \\
I am satisfied with emergency services during travel. \\
I am satisfied with safety and security services during travel. \\
I am satisfied with beauty and pleasing services during travel. \\
I am satisfied with attitude and behavior of local residents during travel. \\
I am satisfied with shopping facilities of local residents during travel. \\
I am satisfied with washroom and toilet facilities during travel. \\
I am satisfied with sports and recreation facilities during travel. \\
I am satisfied with communication (mobile and internet) facilities during travel. \\
I am satisfied with transportation facilities during travel. \\
I am satisfied with touristic spots cleanness during travel. \\
I am satisfied with tourist guides and tourism guidance information during travel. \\
I do not like presence of hawkers and beggar during travel. \\
I am satisfied with the nightlife during travel. \\
I am satisfied with relaxation facilities during travel. \\
\hline
\end{tabular}

Google link to the Saudi tourism questionnaire: https:/docs.google.com/ forms/d/1eow_LN3HFAVFP1ztseI3gkUliiqbYpZwMGvUaoSbD-Q/edit 